\title{
INCREASED AWARENESS OF GREEN STRATEGY TO SUPPORT THE SUSTAINABILITY OF FOOD SMES IN SOUTH MERUYA WEST JAKARTA
}

\author{
Sawarni Hasibuan and Erry Rimawan \\ Universitas Mercu Buana Jakarta, Indonesia.
}

\begin{abstract}
The government now is always trying some efforts and policy to support competitiveness of Small and Medium Enterprise (SMEs) in Indonesia. Food SMEs is one of SMEs which the quantity is very big and spreading in various location commonly near the housing and business center. Entrepreneurs of Food SMEs is also included in the entity to get attention from the government to increase the competitiveness. Environmental dynamics and care of city community of environmental problems encourage the food's entrepreneurs to adopt green strategy in the process of production in order to get better image so that it can contribute to the sustainability of SMEs. One approach to be adopted is green productivity strategy. Green productivity strategy tries to take care of the environment by the entrepreneur not only from the environmental benefit but also financial benefit, because production process will be operating with minimal waste and efficiency of course will produce benefit financially. This activity has the purpose to increase awareness of green strategy implementation in Food SMEs in District South Meruya West Jakarta. Conducting the activity is done in one months. The approach used is to integrate lecturing, discussion and question answer, self assessment, and simulation. To measure effectivity of the activity have deployed questionnaire pre test and post test related to ability of knowledge, assessment, and analysis of opportunity and application of green strategy in the production chain Food SMEs. The outing target of the activity is increasing the knowledge and ability of SMEs entrepreneurs about the green implementation in production activity. The results of this training show that participants are able to identify the potential of solid waste on the production process that can be processed into value-added products.
\end{abstract}

Keywords: Green Strategy, Waste, Food SMEs.

\section{INTRODUCTION}

Small and medium enterprise (SMEs) play an important role in the economy of the country, both developed and developing countries. In Indonesia the role of SMEs has been proved at the time of economic crisis. The real contribution of SMEs is seen from GDP (Gross Domestic Products) and the absorbtion of labors. The government is always efforting some policies to encourage competitiveness of SMEs nationally. Ministry of industry is also directing our local SMEs to be more focused in market targeting by developing nine priority excellent comodities. Starting from ocean products, coffe, funitures, woven cloth, essential oil, jewelry, non mechanical farm machine and eficient technology, transportation component, and also electronic and telematic products.

The countries targeted for promoting and marketing Indonesian products of SMEs among others are: Australia, Japan, Dubai World Trade Centre, Moscow, Frankfurt, Hongkong, Singapure, and Hanover. In the year 2017 besides subsidice of machinery and tools for 150 SMEs, the government helped to facilitate extention of market for SME's products through promotion and marketing products for 160 SMEs. Ministry of Industry also planned to improve database of SMEs in Indonesia in order to become the reference of development programs of SMEs nationally conducted by Ministry of Industry. In 2018 the government tried to optimalized potential of SMEs in order to become the showcase of our own products and not only become the reseller of other countries products through targeting the market of SMEs and other needs of SMEs which is integrated in the program of eSmart SMEs.

As SMEs will develop the market into global market, it is demanded that SMEs is always increasing and improving the performance in order to always survive and even to win the competition with the competitors. The effort to be done is by increasing the productivity. Productivity is something which is very important for a company as an instrument to monitor production performance. Productivity can also be done to know the whole performance level of a company, it can also become the reference to do continual improvement. As the consequence of of increasing the production, there exist many environmental problems.

The problems are because production process sometimes cause waste of material and energy which will burden to the environment, while good production process not only pay attention to safety and side effect of processed residue waste, but also reduce the waste produced. Problems of environment are oftenly ignored by enterpreneurs of SMEs, while nowadays environmental problems is hot issues to talk about. Therefore, it is very 
important for SMEs enterpreneurs to pay attention to the aspects of environment in each production process conducted to create the harmony with the environment.

Based on those facts, Food SMEs in the district of South Meruya the potential to produce waste pollution. So it is necessary to make improvement in the production process as well as in the management of liquid waste and solid waste produced from the production process. In practice, Food SMEs manufacture certainly expected financial profit from increasing the productivity produced from efficiency of resources in improving environmental management. There are two needs to harmonize, those are the need for economy and the need for protecting the environment. To acomodate the two needs, it is used the method of green productivity. Green productivity is a strategy to increase productivity of a company and performance of environment at the same time in the whole social economy development (APO, 2003). Starting from analyzing the process including input and output, green productivity can produce significant benefit for increasing productivity. From here, it is expected that enterpreneurs of SMEs can achieve higher productivity or in the same time can protect the environment which will lead to creation of sustainable development.

The purpose of this activity is to increase awareness of green strategy in the production process of Food SMEs by identifying the potential of solid waste and liquid waste that can be utilized into value-added products to support sustainability Food SMEs in the future.

\section{METHOD}

The public targeted in this community dedication is SMEs food entrepreneurs in the region of South Meruya. The training was conducted in May 2019.

\section{Participants}

Participants of this activity was entrepreneurs of Food SMEs in the district of South Meruya West Jakarta those are housewives joined in RPTRA Mahkota South Meruya West Jakarta.

\section{Approach}

Method of training in increasing awareness of green strategy in food processing with the method of green strategy implementation in Food SMEs are 1) delivering material about the identification of solid and liquid waste in the food production process and its implications on environmental pollution, 2) delivering best practices case of the utilization of solid waste for value-added products in the food industry, and 3) give entrepreneurs the ability to assess waste in potentially exploited into value-added products.

The training used three approaches in delivering the materials those are lecturing, Focus Group Discussion (FGD), Evaluation. Materials of the training is about application of green strategy in food processing.

Through this training activity, small-scale food entrepreneurs in South Meruya can utilize the resulting waste that is able to provide value added profit while also contributing to maintaining the environment in a sustainable manner.

\section{RESULT AND DISCUSSION Profile of Participant}

All participants in this activity are muslims dominated by ethnic Betawi (51 percent and Javanese 31 percent). From the job aspect, dominantly are housewives 86 percent and those who has started the job as enterpreneurs are only 9 percent. Kinds of enterpreneurship interested by most participants (74 percent) is in food business because of more open market and in accordance with skills trainingwhich has been given before. The age of participants who are less than 40 years old are 16 percent, dominantly are between 40 years old until 50 years old. The housewives who are 50 years old until 60 years old are 18 percent, the rest 29 percent are above 60 years old. In the aspect of income, the biggest proportion (43 percent) has faimily income around IDR 2.0 million until IDR. 3.5 million, 26 percent of participants get income more than IDR 3.5 million per month the rest is 31 percent only get income les than IDR. 2.0 million per month.

The types of training previously followed by the participants were presented in Table 1 . The type of training that businesses expect in South Meruya is in the field of production and marketing. This activity is classified as activities in the production process in accordance with the competence of the proposal of the Masters of Industrial Engineering Program. More specifically the aspects that are addressed in the production field using a 
green productivity approach is expected to contribute to the increase in sustainability of the IKM Food South Meruya.

Table 1 The types of training that participants have participated in

\begin{tabular}{lrr}
\hline \multicolumn{1}{c}{ Kind of Training } & $\mathrm{f}$ & $\%$-tase \\
\hline \hline Food & 26 & $74 \%$ \\
Make up and beauty & 3 & $9 \%$ \\
Creative products & 3 & $9 \%$ \\
Others & 3 & $9 \%$ \\
\hline Amount & 35 & $100 \%$ \\
\hline \hline
\end{tabular}

\section{Green Strategy in Food SMEs}

Every production activity, including production activities conducted by small-medium enterprises of food (Food SMEs), will produce a number of waste that can have a negative impact on the environment. The negative impact of waste generated by small food business is also not negligible, because if all the food industry does not care about environmental pollution will contribute to greater problems in urban areas including virtuous, etc.

Contribution of industry to Bruto Domestic Product (PDB) Indonesia is between 25.45 - 28.96 percent with the tendency to rise. This is in accordance with the government effort to strenghen the income from non gas-oil sector and the growth of industrial sector encouraged to achieve the average of 9,75 percent in the period of 2020-2025. However to achieve the target of that industrial growth is not easy, there are many challenges mainly related to increasing competitiveness some of which are problems of natural resources limitation, and also dependence on imported raw material until the problem of waste burden. In global level, the demand to apply industrial standard which focuses on the effort of efficiency in raw material, water and energy, eco-design and low carbon technology with the target increasing productivity and minimalising the waste is becoming higher. Issue of environment ( green issue ) now is becoming one of many barriers to trade to penetrate the market of a country.

To support the changing from industrial sector in Indonesia from Business as Usual (BAU) becomes Green Business some steps have been done. In September 2009 with 20 other Asian countries, Indonesia signed Manila Declaration on Green Industry in Philipine. In the declaration, Indonesia stated the willing to determine the policy, framework of rules and institution encouraging the change to the direction of industry which is efficient and low carbon or known as green industry. Green industry is the industry in which in the production process prioritizing the effort of efficiency and effcetivity of using sustainable resources so that it can harmonize industrial development with environmental preservation and alsocan give benefit for the society.

Applying green industry is done through the concept of cleaner production through application $4 \mathrm{R}$, those are Reduce, Reuse, Recycle, and Recovery. To make more effective the application of cleaner production, principle of Rethink (concept of thinking in the beginning of operational activity) can be added to become 5R. Besides, cleaner production also involves the effforts to increase eficiency of using raw material, supporting material and energy in all stages of production. By applying the concept of cleaner production, it is expected that natural resources can be preserved more and be utilized sustainably. Shortly, celaner production gives two benefits, first efficiency in production process; and second minimalising the forming of waste, so it can protect the harmony of life environment.

The need to increase competitiveness to higher level with lower environmental effect encourages industry for the paradigm known as green manufacturing. Implementation of green manufacturing in industry is not easy because of some reasons and not giving significant effect in industrial world especially in developing countries. Green manufacturing is closely related with sustainable manufacturing (SM). Sustainability can be gained by doing concept of green (Dornfeld, 2014; Tseng, et al., 2013). Application of sustainable manufacturing leads to achievement of sustainable development as stated by World Comission about Environment and Development (Dornfeld, 2013) is defined as "The development to fulfill the needs of nowadays without sacrifying ability of next generation to fulfill their own needs." 

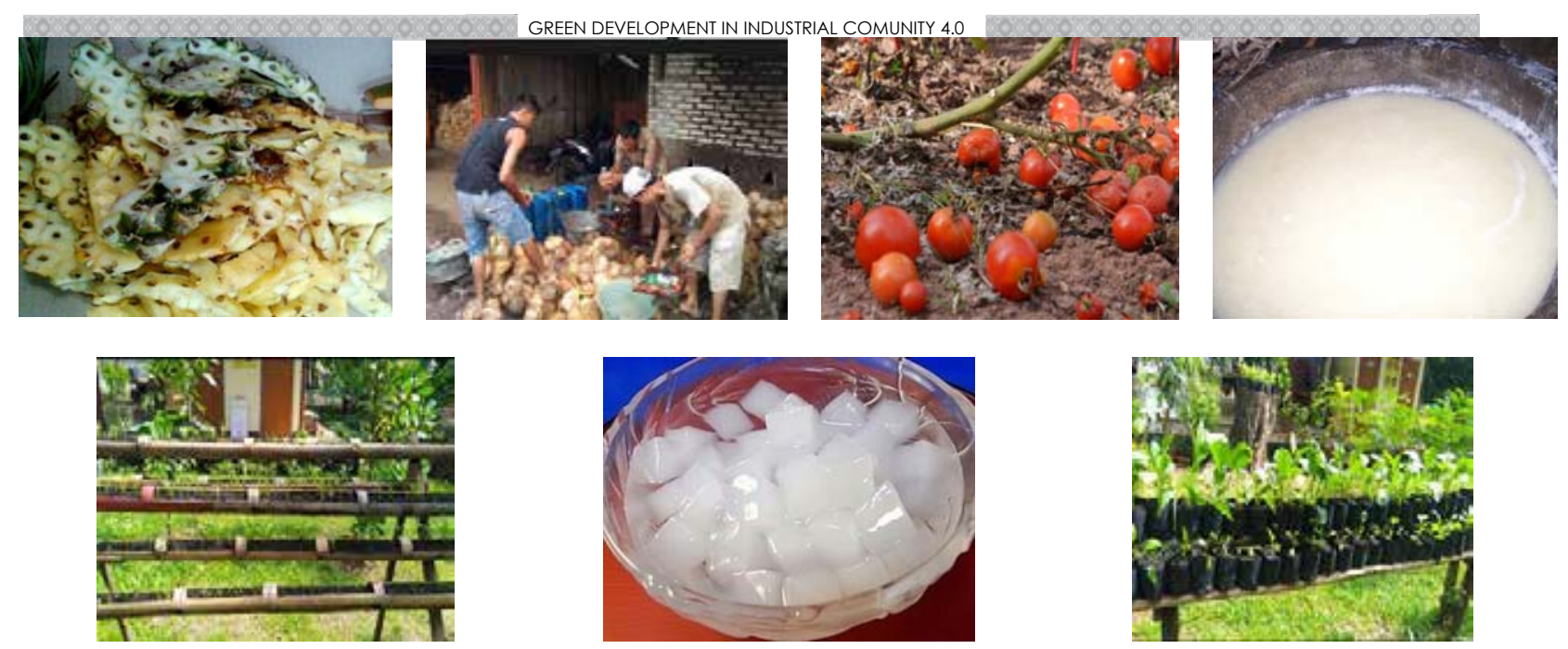

Figure 1 Various food waste that can be processed into food i.e. nata and fertilizer

\section{Evaluation of Result Activity}

After finishing training of green strategy in South Meruya, was done evaluation about benefit and understanding and potential of implementing green concept among training participants. Result of evaluation showed that all participants $(100 \%)$ have never got training about green concept before, so the material of training was considered important by all participants $(100 \%)$. From the aspect of conducting the activity 47 percent participants stated very good about location of training, and 35 percent stated good. No participant gave negative evaluation about training facility. About the understanding, most of the participants (90\%) stated can understand the material training green strategy in Food SMEs. The material and moduls of training handed out to the participants was considered very good by 35 percent participants and was considered good by percent participants, 18 percent participants gave opinion sufficient. From aspect of conducting activity sosialization of green concept is considered very good and good by all participants.
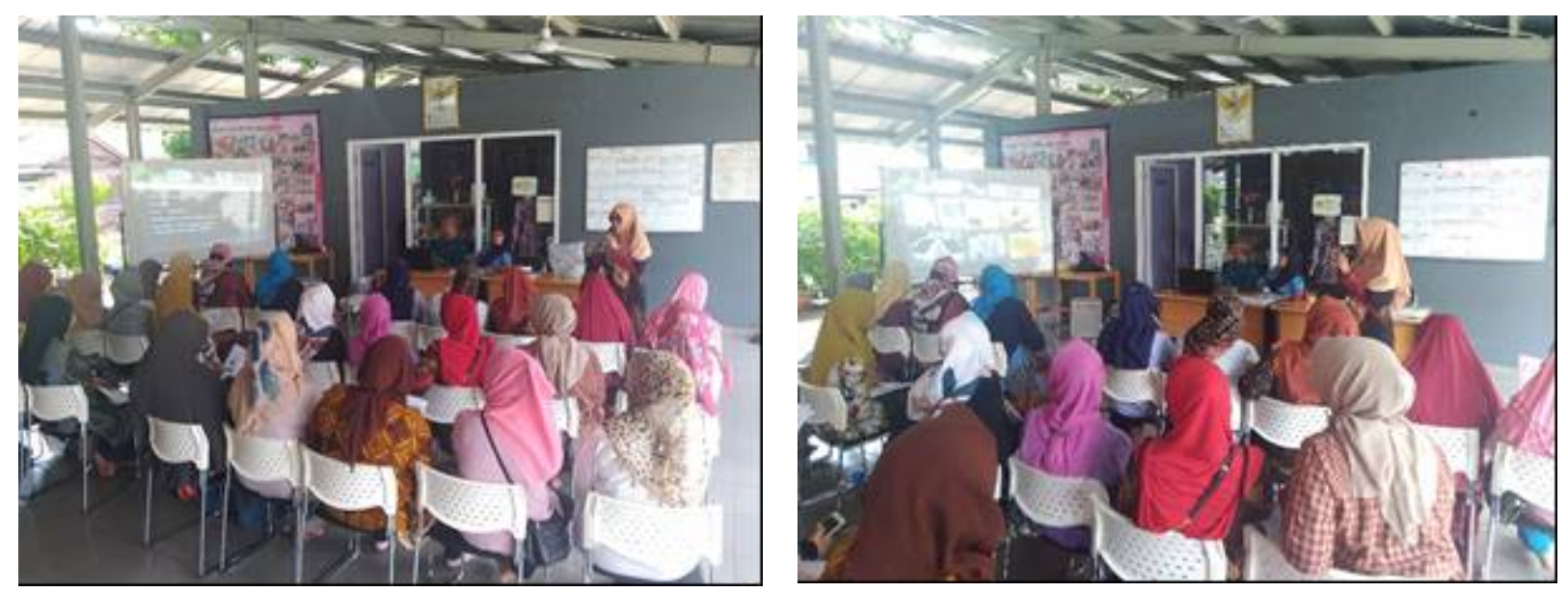

Figure 2 Participants are enthusiastic to follow the green strategy training activities

\section{CONCLUSION AND SUGGESTION}

\section{Conclusion}

The demand for implementing green concept are not only faced by large and medium scale industry but also small scale industry which has potential for more flexible market developing. It also need to increase the care for implementation of green concept. The training has the purpose to increase the care of enterpreneurs of SMEs manufacture District South Meruya for green manufacturing.

Increasing awareness of green concept for entrepreneurs of Food SMEs is very necessary. Entrepreneurs of Food SMEs was introduced to various kinds of solid waste and liquid waste. The results of the training showed there are the increased awareness of participants to the green strategy increases, the ability of participants to identify potential waste that can be increased added value also increases. Proven one of the participants who 
produce soy milk identifying liquid and solid waste that can still be processed into nata de soya besides only utilized as organic fertilizer.

\section{Suggestion}

During the training, the production of Nata de Coco was done due to the constraints of starter arrival. Participants need to mentoring the production project of Nata de Coco in the next activity because there are business actors who demonstrate the enthusiastic to develop the diversification of nata products.

\section{REFERENCES}

Agustina. (2010). Spesialisasi dan Konsentrasi Spasial Industri Kecil Menengah di Kota Semarang. Unpublished Paper. Skripsi. Fakultas Ekonomi Universitas Diponegoro Semarang.

Asian Productivity Organization, (2001), Green Productivity Practice: In Selected Industry Sectors, Asian Productivity Organization, Tokyo,

Asian Productivity Organization, (2002), Green Productivity: Training Manual, Asian Productivity Organization, Tokyo

Aziz, F. (2008). Pembinaan UKM Tumpang Tindih. Diakses dari http://finance.detik.com/read/2008/04/19/ 105711/925902/4/pembinaan-ukm-tumpang-tindih (12 Oktober 2013).

Billatos, S. B. and N.A. Basaly, 1997, Green Technology and Design for The Environment, Taylor \& Francis

BAPEDAL Propinsi Jatim, (2002), Keputusan Gubernur Jatim No.45 tahun 2002 tentang baku mutu limbah cair bagi industri atau kegiatan usaha lainnya

Djamhari, C. (2006). Faktor-faktor yang Mempengaruhi Sentra UKM Menjadi Klaster Dinamis. Infokop Nomor 29 Tahun XXII: 83-91.

Hidayat, M.S. (2012). Daya Saing IKM Perlu Ditingkatkan. Diakses dari http://www.kemenperin.go.id/artikel/ 5210/Daya-Saing-IKM-Perlu-Ditingkatkan (9 Oktober 2013). 